\title{
Aggression and the general practitioner
}

\author{
Paul D’Urso, Richard Hobbs
}

The growing concern over violence against health service staff is reflected in an increasing number of anecdotal reports in both the medical and the lay press describing violent incidents..$^{1.3}$ Family practitioner committees have recently started to gather information on the subject.

The Health and Safety Commission has described some of the common factors in assaults against employees. ${ }^{+}$These include difficulties patients experience in gaining access to medical help and disturbed personalities. Drugs and alcohol, job location, prolonged waiting, and working alone also contributed to the risk. The Department of Health and Social Services advisory committee on violence to staff emphasised the vulnerability of doctors when performing home visits. It noted that general practitioners have no formal system for reporting violence and must personally identify and fund any initiatives to reduce risk.

The only published study of violence towards general practitioners concerned doctors in five health authorities. ${ }^{6}$ In the year preceding the survey $0.5 \%$ of general practitioners had suffered major injuries and $0.5 \%$ minor injuries, $5 \%$ had been threatened with a weapon, and $24.9 \%$ had received verbal abuse.

In this study we attempted to assess the extent of violence in a sample of urban practices.

\section{Method}

A postal questionnaire was sent to all general practitioners with a surgery address in the Sparkhill, Sparkbrook, Harborne, Quinton, and Hall Green wards of Birmingham during July $1987(n=83)$. Sparkhill and Sparkbrook are inner city wards, with high rates of unemployment and much accommodation of poor quality.' Sparkbrook is among the 50 most underprivileged wards as regards health in England and Wales. ${ }^{8}{ }^{9}$ Harborne, Quinton, and Hall Green are more suburban and less socially deprived.

The questionnaire divided aggressive behaviour into verbal abuse, attempted physical injury, and actual physical injury. Additional information was requested on the number of aggressive attacks, the role of drugs or alcohol, the location and timing, the person responsible, and the times when the general practitioner felt that he or she was under threat.

Department of General

Practice, Birmingham

University,

Birmingham B15 2TJ

Paul D'Urso, medical student

Richard Hobbs, MRCGP,

senior lecturer

Correspondence to:

Dr Hobbs.

Br Med f 1989:298:97-8

\section{Results}

Of the 83 questionnaires sent, 66 replies were received, representing a response rate of $80 \%$. Significantly more doctors had experienced verbal abuse (60; $91 \%)$ than either attempted injury $(12 ; 18 \%)$ or actual injury $(7 ; 11 \%)(p<0.001)$ (table I). Significantly more inner city than suburban doctors had suffered attempted injury $(p<0.05)$, though there was no difference for verbal abuse or actual injury. The sex of the doctor did not influence the numbers.

Most aggressive incidents occurred in the surgery (table II), but actual injuries happened as often on night visits. Sixteen (24\%) doctors had felt under threat in surgery hours and during evenings on call, but $26(39 \%)$ had felt under threat when on call at night. Only four respondents had experienced

TABLE I-Frequency of aggressive episodes reported by general practitioners. Figures are numbers (percentages)

\begin{tabular}{llllrr}
\hline & \multicolumn{5}{c}{ Frequency of episodes } \\
\cline { 2 - 6 } Type of episode & $\begin{array}{c}\text { Once a } \\
\text { week }\end{array}$ & $\begin{array}{c}\text { Once a } \\
\text { month }\end{array}$ & $\begin{array}{c}\text { Once a } \\
\text { year }\end{array}$ & Occasionally & Never \\
\hline $\begin{array}{l}\text { Verbal abuse } \\
\text { Attempted physical injury } \\
\text { Actual physical injury }\end{array}$ & $2(3)$ & $4(6)$ & $9(14)$ & $45(68)$ & $6(9)$ \\
& & $1(>1)$ & $2(3)$ & $9(14)$ & $54(82)$ \\
\end{tabular}

TABLE II-Number (percentage) of episodes of violence towards general practitioners in the surgery and on domiciliary visits

\begin{tabular}{lrrr}
\hline & & \multicolumn{2}{c}{ Domiciliary visit } \\
\cline { 3 - 4 } Type of episode & Surgery & $\begin{array}{c}\text { During surgery } \\
\text { hours }\end{array}$ & Out of hours \\
\hline Verbal abuse & $44(67)$ & $21(32)$ & $25(38)$ \\
Attempted physical injury & $8(12)$ & $4(6)$ & $4(6)$ \\
Actual physical injury & $4(6)$ & $2(3)$ & $3(5)$ \\
\hline
\end{tabular}

aggression from members of the public. Patients and their relatives were equally responsible for the remaining incidents. Alcohol was reported as a precipitating factor by $32(48 \%)$ doctors and drugs by $27(41 \%)$ Several doctors volunteered the information that problems were also caused by violence from psychiatrically disturbed patients and aggression directed against receptionists.

Doctors stated that good interpersonal skills were the most important preventive factor. Several thought that violence was getting worse, and three had started using deputising services only because of concerns over their own safety.

\section{Discussion}

The existence of certain risks, such as infectious disease and violent patients, must be accepted as an inevitable feature of medical practice. But for the seven (11\%) general practitioners in this survey who suffered actual injury during their work this is an unnacceptable hazard. Furthermore, nearly a quarter of the 66 doctors tolerated regular verbal abuse. Although we studied a small sample of general practitioners, the figures are similar to those produced by the Health and Safety Commission. ${ }^{4}$ Unfortunately, the fear of attack is as much of a problem as the actual aggression, particularly during the night when making calls. This fear is worthy of more detailed examination. How much the threat of violence contributes to the transfer of night visits to deputising services remains to be answered. Most aggression towards general practitioners, however, takes place in the surgery. 
General practitioners need to plan their services to reduce the risk of violence. This should include providing adequate training and support for reception staff and sufficient space in the waiting area, avoiding keeping patients waiting a long time, and having a practice policy on how to handle patients who are obviously disturbed or under the influence of drugs or alcohol.

The findings in this survey concur with those of the Health and Safety Commission that the doctor's interpersonal skills were an important limiting factor. ${ }^{6}$ Teaching communication skills to undergraduates improves their consulting performance ${ }^{1011}$ and confidence in handling difficult patients, and more emphasis should be laid on this in medical school. Additional training should take place on vocational training schemes.

Further research is needed into violence against all members of the primary health care team in both urban and rural practice. We do not know whether violence towards general practitioners is increasing, but they remain an easy and accessible target.

1 Cembrowicz S. Assault on a GP. Br Med f 1987;294:616-8.

2 Wells F. Assault. Br Med f 1983;286:113-4.

3 Leppard D. Health squads fight hospital crime wave.-Sunday Times 1988 July 24:A5 ( $\mathrm{col} 1-4)$

4 Health and Safety Commission. Violence to staff: a basis for assessment and prevention. London: HMSO, 1986.

5 Department of Health and Social Security Advisory Committee on Violence to Staff. Report. London: HMSO, 1988.

6 Health and Safety Commission. Violence to staff in the health service.. London: HMSO, 1987

7 City of Birmingham Development Department. Ward fact sheets (Sparkhill, Sparkbrook, Harborne, Quinton and Hall Green). Birmingham: Development Department, 1986

8 Jarman B. Identification of underprivileged areas. Br Med J 1983;286: 1705-9. Jarman B. Underprivileged areas: validation and distribution of scores. BrMed f 1984:289:1587-92.

10 Burnett AC, Thompson DG. Aiding the development of communication skills in medical students. Med Educ 1986;20:424-31.

11 Maguire P, Fairbairn S, Fletcher C. Consultation skills of young doctors. Br.Med f 1986;292:1573-8.

(Accepted 28 November 1988)

\section{BOOKS RECEIVED}

\section{Dentistry}

Complications of Sedation and Anaesthesia in Deniistry. G D Hayden Jr. (Pp 368; £30 paperback.) Massachusetts: PSG Publishing Com pany, 1988. Distributed by Butterworth. ISBN 0-88416-555-8.

\section{Dermatology}

Practical Cutaneous Cryosurgery. D Torre, R R Lubritz, E G Kuflik. (Pp 144; figs; £44.45.) Connecticut: Appleton and Lange, 1988. Distributed by Prentice-Hall. ISBN $0-8385$

Surgical Anatomy of the Skin. S J Salasche, G Bernstein, M Senkarik. (Pp 304; figs; f79.95.) Connecticut: Appleton and Lange, 1988. Distributed by Prentice-Hall. ISBN $0-8385$ 8709-7.

\section{Endocrinology}

Clinical Neuroendocrinology. Ed R Collu, G M Brown, G R Van Loon. Collu, G M Brown, G R Van Loon.
(Pp 624; figs; $£ 62.50$.) Boston: BlackPp 624; figs; 162.50 .) Boston: Black-
well Scientific, 1988. ISBN 0-86542well S.

Diagnosis and Pathology of Endocrin Diseases. G Mendelsohn. (Pp 756; figs; £65.) Philadelphia: Lippincott, 1988 Distributed by Harper and Row ISBN 0-397-50731-3.

Frontiers in Reproductive Endocrinology and Fertility. Ed C S A Ng, F M M Tsakok, Seang-Lin Tan, Kong-Hon Chan. (Pp ix +112 ; figs; £25.) Dordrecht: Kluwer, 1988. Distribu-
ted by MTP Press. ISBN 0-7462ted by

Steroid Receptors and Disease: Cancer, Autoimmune, Bone, and Circulatory Disorders. Ed P J Sheridan, K Blum, M C Trachtenberg. (Pp xvi+580; figs; \$150.) New York: Dekker, 1988 .
15 Trachtenberg. (Pp xvi 580 ; figs; \$150.) New York:
ISBN 0-8247-7954-1.

\section{Gastroenterology}

Advances in Peptic Ulcer Pathogenesis. Ed W D W Rees. (Pp xi+244; figs; £42.50.) Lancaster: MTP Press, 1988 ISBN 0-7462-0062-5.

Gastric Protection. Ed R Cheli, F Berri, F Molinari, F C Parodi. (Pp 312; figs; $\$ 107.50$.) New York: Raven Press, 1988. ISBN 0-88167-436-2.

Recent Advances in Gastroenterology. No 7. Ed R Pounder. (Pp viii +400 figs; £39.) Edinburgh: Churchil Livingstone, 1988. ISBN $0-443$ 04027-3.

Techniques in Therapeutic Endoscopy. J Venu. (Pp 160; figs and colour plates;
£39.50.) Philadelphia: Lippincott/ New York: Gower, 1988. Distributed by Gower Medical Publishing. ISBN 0-397-44672-1.

General medicine

Diagnosis of Chest Pain. A J Miller. (Pp 240; figs; \$61.50.) New York: Raven Press, 1988. ISBN 0-88167-400-1.

\section{Genetics}

Progress and Topics in Cytogenetics. Vol 8. "The Cytogenetics of Mammalian Autosomal Rearrangements." Ed A Autosomal Rearrangements." Ed A Daniel. Series editor A A Sandberg.
(Pp 944; figs; \$295.) New York: Liss, 1988. Distributed by John Wiley and 1988. Distributed by John W
Sons. ISBN 0-8451-2410-2.

\section{Genitourinary tract diseases}

The Bloomsbury Series in Clinical Science. "Diseases in the Homosexual Male." Ed M W Adler. Series editor J Tinker. (Pp xii + 204; figs; £29.50.) London: Springer, 1988. ISBN 354019521-1.

\section{Geriatrics}

Advanced Geriatric Medicine 7. Ed J Grimley Evans, F I Caird. (Pp 200; figs; £40.) London: Wright, 1988. Distributed by Butterworth. ISBN 0-7236-1343-5.

\section{Haematology}

Contemporary Issues in Haemostasis and Thrombosis. Vol 3. "Protein C and Related Proteins: Biochemical and Clinical Aspects." Ed R M Bertina. (Pp 244; figs; £ 45.) Edinburgh: (Pp 244; figs; £45.) Edinburgh: 443-03751-5.

\section{Health care issues}

Elimination or Reduction of Diseases? Opportunities for Health Service Action in Europe. Ed A J Silman, S P A Allwright. (Pp xvi +370 ; figs; £30.) Oxford: Oxford University Press, 1988. ISBN 0-19-261700-1.

European Health for All Series. No 2. "Research Policies for Health for All." World Health Organisation. (Pp ix + 46; Sw frs 8 paperback.) Copenhagen 46; Sw frs 8 paperback.) Copenhagen:
World Health Organisation Regional Office for Europe, 1988. ISBN 92-8901053-3.

European Health for All Series. No 3. "Priority Research for Health for All." World Health Organisation. $\mathrm{Pp} x+$ 164; Sw. frs 15 paperback.) Copenhagen: World Health Oranistion Regional Office for Eurganisation ISBN 92-890-1054-1.
A New Kind of Doctor: the General Practitioner's Part in the Health of the Community. J Tudor Hart. (Pp 380 £11.95.) London: Merlin Press, 1988 ISBN 0-85036-299-7.

Psychology and Medicine Series. "Communicating with Patients: Improving Communication, Satisfaction and Compliance." P Ley. Series editor D Marcer. (Pp xviii+210; figs; $\$ 9.95$ paperback.) London: Croom Helm 1988. ISBN 0-7099-4174-9.

\section{History of medicine}

The Anatomy of Madness: Essays in the History of Psychiatry. Vol 3. "The Asylum and Its Psychiatry." Ed W F Bynum, R Porter, $M$ Shepherd. ( $P p$ $\mathrm{xi}+353$; index; £35.) London: Routledge, 1988. ISBN 0-415-00859-X.

Belfast: 100 Years of Public Health. $\mathrm{R}$ Blaney. (Pp viii +84 ; figs; $\{2.95$ paperback.) Belfast: Belfast City Counci and Eastern Health and Social Service Board, 1988. ISBN 0-901999-03-2.

Cecilia Street: the Catholic University School of Medicine 1855-1931. F O C Meenan. (Pp xiv +144; figs; 115 .) Dublin: Gill and Macmillan, 1988. Dublin: Gill and Macm
ISBN 0-7171-1539-9.

Doctors and Diseases in the Roman Empire. R Jackson. (Pp 208; figs £17.50.) London: British Museum Publications, 1988. ISBN 0-71411390-5.

A History of the Imperial Cancer Research Fund 1902-1986. J Austoker (Pp xvii $+375 ; £ 40$.) Oxford: Oxford University Press, 1988. ISBN 0-19723075-X.

On Soul and Conscience: the Medical Expert and Crime. 150 Years of Forensic Medicine in Glasgow. M A Crowther, B White. (Pp 188; figs; £14.90 hardback, 57.95 paperback.) Aberdeen: Aberdeen University Press, 1988. ISBN h/b 0-08-036406-3, p/b 0-08-036407-1.

Tavistock Classics in the History of Psychiatry. "An Essay Medical, Philosophical, and Chemical on Drunken ness and Its Effects on the Huma Body by Thomas Trotter." Edited with an introduction by $\mathrm{R}$ Porter. General editors W F Bynum, R Porter. (Pp 320; £19.95.) London: Routledge, 1988. ISBN 0-415-00636-8.

Tavistock Classics in the History of Psychiatry. "Illustrations of Madness by John Haslam." Edited with an introduction by $R$ Porter. General editors W F Bynum, R Porter. (Pp 224; £17.) London: Routledge, 1988. ISBN 0-415-00637-6. Tavistock Classics in the History of
Psychiatry. "Lifes Preservative Against Psychiatry. "Lifes Preservative Against
Self-Killing by John Sym." Edited

with an introduction by $M \mathrm{Mac}$ Donald. General editors W F Bynum, R Porter. (Pp 448; figs; 229.95 . London: Routledge, 1988. ISBN 0415-00639-2.

Tavistock Classics in the History of Psychiatry. "Observations on Maniacal Disorders by William Pargeter." Edited with an introduction by $S$ Jackson. General editors W F Bynum, $\mathrm{R}$ Porter. (Pp 256; f17.) London: Routledge, 1988. ISBN $0-415$ 00638-4.

\section{Immunology}

Advances in Immunomodulation. Ed Bizzini, E Bonmassar. (Pp 544; fig £40.) Milan: Pythagora Press, 1988 Available from Epsilon Press, The Distribution Centre, Blackhorse Road Letchworth, Herts SG6 IHN. ISBN 88-85852-06-8.

Developments in Hematology and Immunology. "Laboratory Animals in Vaccine Production and Control." $\mathrm{C}$ M Hendriksen. (Pp xvii + 158; 227.50 .) Dordrecht: Kluwer, 1988. Distribute by MTP Press. ISBN 0-89838-398-6.

Immunology and Immunologic Diseases of the Lung. Ed R P Daniele. (Pp 728 figs; £75.) Boston: Blackwell Scientifigs; f75.) Boston: Blackwell
fic, 1988. ISBN 0-86542-035-1.

Immunology Series. Vol 41. "Cellula Oncogene Activation." Ed G Klein. Series editor N R Rose. ( $P p$ xv +396 figs; $\$ 132$.) New York: Dekker, 1988 ISBN 0-8247-7983-5.

Immunology Series. Vol 42. "Interferon and Nonviral Pathogens." Ed G Byrne, Jenifer Turco. Series editor $\mathrm{R}$ Rose. (Pp xiv + 317; figs; $\$ 119.50$. New York: Dekker, 1988. ISBN 08247-7973-8.

\section{Neurology}

Atlas of Neuropathology. H Okazaki, B W Scheithauer. (Pp 336; colour plates; f80.) New York: Gower Medical Publishing/Philadelphia: Lippincott, 988. ISBN 0-397-44667-5.

Essential Neurology. I M S Wilkinson. 